\title{
The delayed appearance of an antinuclear factor and the diagnosis of systemic lupus erythematosus in glomerulonephritis
}

\author{
S. A. CaIrns \\ B.SC., M.R.C.P. \\ C. L. CORBETT
M.R.C.P.
}

W. LAWLER*

M.B. B.S.*
E. J. ACHESON
M.D.

S. Dosa

M.D., M.R.C.P.

N. P. Mallick

B.Sc., M.B., F.R.C.P.
Summary
In 11 patients who presented with apparently idiopathic glomerular disease the antinuclear factor (ANF) was absent initially but was eventually detected during observation extending over 6 years. In 4 patients a diagnosis of systemic lupus erythematosus (SLE) has now been made and the disease treated. Of the remaining 7, 2 had conditions known to be associated with a positive ANF, and in 4, drug therapy induced the ANF. Clinical features, complement studies and measurement of anti-DNA antibody were of value in distinguishing those patients with SLE from the others.

\section{Introduction}

Prompt treatment may dramatically affect the outcome of lupus nephritis (Cathcart et al., 1976; Levinsky, Cameron and Soothill, 1977; Dosa et al., 1978). It is therefore crucial to distinguish it from idiopathic glomerulonephritis as early as possible but this may be difficult especially in the absence of extrarenal manifestations of systemic lupus erythematosus (SLE), since renal biopsy appearances are not diagnostic (Simenoff and Merrill, 1964). The detection of circulating antinuclear factor (ANF) is widely used as a screening test for SLE and while false positive results are common (Svec and Veit, 1967; Bartholomew, 1974; Burnham, 1972; AlarconSegovia, 1976), the test is so sensitive that some authorities suggest that a single negative ANF excludes the diagnosis (Hughes, 1974; Friou, 1972).

Eleven patients were seen who developed glomerulonephritis and in whom the ANF was initially negative but subsequently became positive. In 4, a diagnosis of SLE has now been made.

\section{The patients}

Details of the 11 patients are given in Table 1. In the first 4 patients SLE has been diagnosed.

\section{Case 1}

A 19-year-old Chinese girl developed a nephrotic syndrome and acute renal failure in 1967. The LE cell test was negative. Her renal function improved with steroids and azathioprine but proteinuria persisted. In February 1972 the ANF was negative. The steroids were tailed off and stopped in November 1972 and, in May 1973, when she was asymptomatic, the ANF became positive. The total haemolytic complement $\left(\mathrm{CH}_{50}\right)$ and $\mathrm{C} 3$ were low. Anti-DNA binding was $22 \%$ (normal range 0-20\%).

\section{Case 2}

A 16-year-old girl developed a nephrotic syndrome in June 1966. The ANF was negative. The proteinuria resolved with steroid therapy. The ANF became positive when the proteinuria recurred in October 1966. During a third relapse in August 1973 the anti-DNA antibody was elevated and $\mathrm{CH}_{50}$ low.

\section{Case 3}

A 49-year-old woman developed a nephrotic syndrome and microscopic haematuria in 1975. The ANF was negative and serum complement normal. Four months later when she was well the ANF 
TABLE 1. Résumé of clinical and laboratory data on 11 patients: Cases 1-4: SLE diagnosed. Cases 5-6: Other conditions associated with a positive ANF. Cases 7-10: Positive ANF associated with drug therapy. Case 11: Unclassified

\begin{tabular}{|c|c|c|c|c|c|c|c|c|c|c|c|}
\hline & \multirow{2}{*}{$\begin{array}{l}\text { Sex and age } \\
\text { (in years) at } \\
\text { onset of } \\
\text { renal lesion }\end{array}$} & \multirow{2}{*}{$\begin{array}{l}\text { Interval: from } \\
\text { onset to } \\
\text { positive ANF }\end{array}$} & \multirow{2}{*}{$\begin{array}{l}\text { Pattern } \\
\text { of } \\
\text { ANF }\end{array}$} & \multirow{2}{*}{$\begin{array}{l}\text { Grade } \\
\text { of } \\
\text { ANF* }\end{array}$} & \multicolumn{2}{|c|}{$\begin{array}{l}\text { A.R.A. } \\
\text { criteria } \\
\text { fulfilled }\end{array}$} & \multicolumn{2}{|c|}{ Complement } & \multicolumn{2}{|c|}{$\begin{array}{c}\text { Anti-DNA } \\
\text { Antibody }\end{array}$} & \multirow{2}{*}{$\begin{array}{l}\text { Response } \\
\text { of renal } \\
\text { lesion to } \\
\text { steroids }\end{array}$} \\
\hline & & & & & $\begin{array}{c}\text { At } \\
\text { onset } \\
\text { of } \\
\text { illness }\end{array}$ & $\begin{array}{l}\text { Sub- } \\
\text { sequently }\end{array}$ & $\begin{array}{c}\text { When } \\
\text { ANF } \\
\text { first } \\
\text { positive }\end{array}$ & $\begin{array}{c}\text { Sub- } \\
\text { sequent }\end{array}$ & $\begin{array}{c}\text { When } \\
\text { ANF } \\
\text { first } \\
\text { positive }\end{array}$ & $\begin{array}{c}\text { Sub- } \\
\text { sequent }\end{array}$ & \\
\hline $\begin{array}{l}1 \\
2 \\
3 \\
4\end{array}$ & $\begin{array}{l}F(19) \\
F \quad(16) \\
F \quad(49) \\
M(19)\end{array}$ & $\begin{array}{l}6 \text { years } \\
5 \text { months } \\
8 \text { months } \\
3 \text { months }\end{array}$ & $\begin{array}{l}\text { Nonspecific } \\
\text { Nonspecific } \\
\text { Nonspecific } \\
\text { Speckled }\end{array}$ & $\begin{array}{c}+++ \\
+++ \\
+ \\
+++\end{array}$ & $\begin{array}{l}2 \\
2 \\
2 \\
1\end{array}$ & $\begin{array}{l}4 \\
4 \\
4 \\
4\end{array}$ & $\begin{array}{l}N \\
\downarrow\end{array}$ & $\begin{array}{l}\downarrow \\
\downarrow \\
\downarrow \\
\downarrow\end{array}$ & $\begin{array}{l}\mathbf{N} \\
\uparrow\end{array}$ & $\uparrow$ & $\begin{array}{l}+ \\
+ \\
+ \\
+\end{array}$ \\
\hline $\begin{array}{l}5 \\
6\end{array}$ & $\begin{array}{l}\text { M (38) } \\
\text { M (59) }\end{array}$ & $\begin{array}{r}17 \text { years } \\
4 \text { years }\end{array}$ & $\begin{array}{l}\text { Speckled } \\
\text { Nonspecific }\end{array}$ & + & $\begin{array}{l}1 \\
2\end{array}$ & $\begin{array}{l}2 \\
2\end{array}$ & $\begin{array}{l}\mathbf{N} \\
\mathbf{N}\end{array}$ & $\begin{array}{l}N \\
\downarrow\end{array}$ & $\begin{array}{l}\mathbf{N} \\
\mathbf{N}\end{array}$ & $\begin{array}{l}\mathbf{N} \\
\mathbf{N}\end{array}$ & $\begin{array}{l}\dagger \\
0\end{array}$ \\
\hline $\begin{array}{l}7 \\
8\end{array}$ & $\begin{array}{l}F \quad(51) \\
M(27)\end{array}$ & $\begin{array}{l}3 \text { years } \\
4 \cdot 5 \text { years }\end{array}$ & $\begin{array}{l}\text { Nonspecific } \\
\text { Nucleolar/ } \\
\text { Homogeneo }\end{array}$ & $\begin{array}{l}++ \\
++\end{array}$ & $\begin{array}{l}1 \\
2\end{array}$ & $\begin{array}{l}3 \\
3\end{array}$ & $\downarrow$ & $\downarrow$ & $\uparrow$ & $\uparrow$ & $\dagger$ \\
\hline $\begin{array}{r}9 \\
10\end{array}$ & $\begin{array}{l}F(39) \\
M(35)\end{array}$ & $\begin{array}{l}3 \text { years } \\
3 \text { years }\end{array}$ & $\begin{array}{l}\text { Nonspecific } \\
\text { Speckled }\end{array}$ & $\begin{array}{c}+++ \\
+\end{array}$ & $\begin{array}{l}2 \\
2\end{array}$ & $\begin{array}{l}2 \\
2\end{array}$ & & $\begin{array}{l}\mathbf{N} \\
\mathbf{N}\end{array}$ & & $\mathrm{N}$ & $\begin{array}{l}0 \\
\dagger\end{array}$ \\
\hline 11 & F (23) & 6.5 years & Nonspecific & + & 2 & 2 & $\downarrow$ & $\mathbf{N}$ & $\mathbf{N}$ & $\uparrow$ & + \\
\hline
\end{tabular}

*Visual assessment; $N$, normal; o, nil; $\dagger$, steroids not given; A.R.A., American Rheumatism Association.

became positive but anti-DNA antibody and complement were normal. The anti-DNA antibody was subsequently elevated in June 1976 when she developed leucopenia and thrombocytopenia and a falling creatinine clearance.

\section{Case 4}

A 20-year-old Indian man developed bilateral loin pain, a deep vein thrombosis and a nephrotic syndrome in December 1975. The ANF was negative. A venogram showed a partial right renal vein occlusion. In February 1976 when his symptoms had resolved but proteinuria persisted, the ANF became positive and the anti-DNA antibody was raised. $\mathrm{CH}_{50}$ and $\mathrm{C} 4$ were low. The Coombs' test was positive, he had cold agglutinins and thrombocytopenia. There were granular casts in the urine. Renograms and scintiscanning demonstrated the resolution of the renal vein thrombosis following steroids and anticoagulants, but proteinuria persisted, the ANF remained positive and anti-DNA antibody, C1q and C3 abnormal.

\section{Case 5}

The ANF in this case was associated with another connective tissue disease.

A 54-year-old man with a 16-year history of rheumatoid arthritis treated with steroids was investigated in 1974 for proteinuria and haematuria. The ANF was negative at this time but positive one year later. He was taking prednisolone $10 \mathrm{mg} /$ day during this period.

\section{Case 6}

A paraprotein may have acted as an $A N F$ in this patient.

A 59-year-old man developed a nephrotic syndrome in 1969. The ANF was negative. He suffered a retinal vein thrombosis in 1970 and a myocardial infarction in 1972. An IgG paraprotein was detected in his serum 9 months after the ANF first became positive in 1973. There was no evidence of malignant myeloma but there were $\mathrm{K}$ light chains in his urine. The anti-DNA antibody was elevated but serum complement was normal. Following cytotoxic therapy the proteinuria almost disappeared, the creatinine clearance rose, the ANF and paraprotein could no longer be detected and the anti-DNA antibody level returned to normal.

Drug therapy is implicated in the development of a positive ANF in 4 patients. In one, penicillamine induced a lupus syndrome.

\section{Case 7}

A 38-year-old woman developed polyarthritis in 1972. Rheumatoid factor and ANF were negative. She started penicillamine therapy in 1974 and 12 months later developed a nephrotic syndrome. The ANF was positive, anti-DNA antibody elevated and Clq low. The penicillamine was stopped and 9 months later the proteinuria had resolved. The ANF remains positive with a grossly elevated anti-DNA antibody. 


\section{Cases 8, 9, 10}

In these 3 patients the ANF became positive after methyldopa therapy. The Coombs' test was positive in Case 8. The development of a positive ANF was unrelated to the clinical condition of the patients and with the exception of an isolated low $\mathrm{C} 3$ in Case 8 , was not accompanied by abnormality of anti-DNA antibody or serum complement. The ANF remains positive in Case 104.5 years after the methyldopa was discontinued.

\section{Case 11}

The final patient apparently has idiopathic glomerulonephritis which has followed a relapsing course. The initial episode in 1968 responded to steroid therapy. $\mathrm{CH}_{50}$ was low in 1973 and in 1974 the ANF, which had previously been negative, became positive while her disease was in remission and she was on no treatment. The anti-DNA antibody was normal. Complement levels have subsequently been normal and the anti-DNA antibody had been elevated on only one occasion and no other features of SLE have emerged.

\section{Renal biopsies}

Renal biopsies have been performed on all 11 patients, repeatedly in 7 , and a wide range of glomerular abnormalities found (Table 2). Initial biopsies from 3 patients (Cases 2, 6 and 7) showed no significant changes at the light microscope level but in all 3, either initially or subsequently, there was immunofluorescent and ultrastructural evidence of glomerular immune complex deposition, and one (Case 6) also showed typical Bence-Jones tubular casts ultrastructurally. Seven patients (Cases 1, 3, $5,8,9,10$ and 11) showed a variable diffuse mesangial proliferative glomerulonephritis in their first biopsies. Of these, 5 (Cases 1, 3, 8, 9 and 10) had repeat biopsies, all of which showed progression towards glomerulosclerosis and in 3 (Cases 1, 3 and 8) this had advanced to an 'end-stage kidney'. The remaining patient (Case 4) showed the classical appearances of established membranous glomerulopathy.

\section{Discussion}

A diagnosis of SLE has been made in 4 of 11 patients in whom the ANF was initially negative. This experience contradicts the view expressed that a single negative ANF is strong evidence against the diagnosis and the test need only be repeated when laboratory error or other cause of a negative ANF, e.g. immunosuppressive therapy, is suspected (Friou, 1972). A delay in the appearance of an ANF was due to steroids in only one of these patients (Case 1). Of the other 3 , it became positive as the clinical illness remitted in 2 and only during a second exacerbation in one.
Case 5 has another connective tissue disease, a frequent cause of a positive ANF (Bartholomew, 1974). In this patient, the delayed appearance of the ANF may have been due to long-term steroid therapy. IgG paraprotein with specific anti-DNA antibody activity has been reported (Cryer and Kissane, 1976) and it is probable that the paraprotein detected in Case 6 was acting as an antinuclear factor. Penicillamine and methyldopa are known to cause lupus syndromes (Elsas et al., 1971; Feltkamp, Dourhout-Mees and Nieuwenhuis, 1970) and these drugs appear to be responsible for the late appearance of an ANF in 4 of the patients (Cases 7, 8, 9 and 10). The immunochemical disturbance may persist after withdrawal of the drug, as in Cases 7 and 10 (Alarcon-Segovia et al., 1967). The pattern of staining of the ANF and titre of antibody are said to be helpful in distinguishing lupus and non-lupus patients (Husain et al., 1974; Epstein, 1977); this was not the case in the present patients although the antibody was not titrated.

The renal biopsies of patients with renal manifestations of SLE show a wide variety of changes on light microscopy (Cameron et al., 1977; Rothfield, 1977) but none of the present patients showed the abnormalities said to be particularly associated with the disease, haematoxyphil bodies, segmental fibrinoid necrosis, hyaline thrombi and 'wire loops' (Pollak, Pirani and Schwartz, 1964; Dujovne et al., 1972; Pollak and Pirani, 1974; Meadows, 1978). The 4 patients in whom SLE was diagnosed illustrate the range of appearances possible in the disease. Renal immunofluorescence is reported to be invariably positive in SLE. IgG is the usual localizing immunoglobulin although both $\operatorname{IgM}$ and $\operatorname{IgA}$ are often found (Koffler et al., 1969; Pollak and Pirani, 1974; Cavallo, Cameron and Lapenas, 1977; Cameron et al., 1977) and no specific patterns of immunoglobulin deposition may be considered specific for the condition. Electron microscopy may also reveal a wide variety of changes and electrondense deposits may be seen in any location (Comerford and Cohen, 1967; Dujovne et al., 1972; Pollak and Pirani, 1974; Baldwin et al., 1977). While subepithelial, intramembranous, subendothelial and mesangial electron-dense deposits were all present together in biopsies from 2 of the lupus patients (Cases 1 and 3), they were also present in a non-lupus patient (Case 9). The changes seen on electron microscopy in Case 8 were attributable to hypertension, and the Bence-Jones tubular casts in Case 6 accord with the finding of a monoclonal immunoglobulin in the patient's serum. Detailed examination of renal biopsy material and the study of the evolution of the renal lesion on repeated biopsies has not helped distinguish between the lupus and non-lupus patients. 
TABLE 2. Summaries of pathological appearances

\begin{tabular}{|c|c|c|c|c|c|}
\hline $\begin{array}{l}\text { Case } \\
\text { number }\end{array}$ & $\begin{array}{l}\text { Biopsy } \\
\text { number }\end{array}$ & Date & Light microscopy & Immunofluorescence & Electron microscopy \\
\hline \multirow[t]{2}{*}{1} & 1st & June 1973 & MPGN $\rightarrow$ sclerosis & $+\operatorname{IgA}, \operatorname{IgM}$ and $\mathrm{C} 3$ & $\begin{array}{l}\text { As LM. Mesangial, sub- } \\
\text { endothelial and occasional } \\
\text { intramembranous EDD }\end{array}$ \\
\hline & 2nd & Sept. 1976 & End-stage kidney & $\begin{array}{l}+++\operatorname{IgM}, \mathrm{Clq} \text { and } \mathrm{C} 4 \\
++\mathrm{IgG} \text { and } \mathrm{C} 3\end{array}$ & $\begin{array}{l}\text { As LM. Mesangial, sub- } \\
\text { endothelial, intramem- } \\
\text { branous and subepithelial } \\
\text { EDD }\end{array}$ \\
\hline \multirow[t]{3}{*}{2} & $1 \mathrm{st}$ & July 1966 & NLMC & Not done & Not done \\
\hline & 2nd & Sept. 1973 & NLMC & All negative & No glomeruli \\
\hline & 3 rd & Feb. 1977 & NLMC & $\begin{array}{l}++\operatorname{IgM} \text { and } \mathrm{C} 4 ;+\operatorname{IgA}, \\
\text { IgG, C3 and } \mathrm{Clq}\end{array}$ & $\begin{array}{l}\text { Occasional mesangial and } \\
\text { paramesangial EDD }\end{array}$ \\
\hline \multirow[t]{3}{*}{3} & $1 \mathrm{st}$ & Oct. 1975 & Variable MPGN & No glomeruli & $\begin{array}{l}\text { As LM. Focal sub- } \\
\text { endothelial EDD. Occa- } \\
\text { sional platelet aggregates. }\end{array}$ \\
\hline & 2nd & March 1976 & Variable MPGN $\rightarrow$ sclerosis & $\begin{array}{l}\text { Focal and segmental } \\
+ \text { IgG and C3 }\end{array}$ & No glomeruli As LM \\
\hline & 3 rd & Dec. 1978 & End-stage kidney & $+\operatorname{IgM}, \mathrm{C} 3$ and $\mathrm{C} 4$ & As LM \\
\hline 4 & $1 \mathrm{st}$ & Sept. 1976 & Membranous & $\begin{array}{l}+++\mathrm{IgG}, \mathrm{Clq}, \mathrm{C} 4 \text { and } \\
\text { Properdin; + + IgA }\end{array}$ & $\begin{array}{l}\text { Predominantly sub- } \\
\text { epithelial and occasional } \\
\text { intramembranous EDD }\end{array}$ \\
\hline 5 & $1 \mathrm{st}$ & March 1975 & MPGN & $+\operatorname{IgA}$ & $\begin{array}{l}\text { As LM. Occasional para- } \\
\text { mesangial EDD }\end{array}$ \\
\hline \multirow[t]{2}{*}{6} & 1 st & Jan. 1970 & NLCM & Not done & $\begin{array}{l}\text { Marginal increase in } \\
\text { mesangium; no EDD } \\
\text { identified }\end{array}$ \\
\hline & 2nd & Nov. 1973 & Mild MPGN $\rightarrow$ sclerosis & $\begin{array}{l}\text { Focal and segmental } \\
+ \text { IgG and IgM }\end{array}$ & $\begin{array}{l}\text { As LM. Occasional } \\
\text { glomerular collagen. } \\
\text { Bence-Jones tubular casts }\end{array}$ \\
\hline 7 & $1 \mathrm{st}$ & Feb. 1976 & NLMC & $++\operatorname{IgG}$ and $\operatorname{IgM}$ & $\begin{array}{l}\text { Mild mesangial increase; } \\
\text { occasional subepithelial } \\
\text { EDD }\end{array}$ \\
\hline \multirow[t]{3}{*}{8} & $1 \mathrm{st}$ & June 1970 & Mild MPGN & Not done & $\begin{array}{l}\text { As LM. Wrinkling and } \\
\text { focal thickening of mem- } \\
\text { branes; occasional intra- } \\
\text { luminal fibrin }\end{array}$ \\
\hline & 2nd & Dec. 1971 & End-stage kidney & Not done & No glomeruli \\
\hline & $3 \mathrm{rd}$ & Oct. 1973 & End-stage kidney & $++\operatorname{IgM}$ and $\mathrm{C} 3$ & $\begin{array}{l}\text { As first biopsy. No EDD } \\
\text { seen }\end{array}$ \\
\hline \multirow[t]{2}{*}{9} & $1 \mathrm{st}$ & Sept. 1969 & MPGN & Not done & Not done \\
\hline & 2nd & Oct. 1973 & Variable MPGN $\rightarrow$ sclerosis & $++\operatorname{IgA}, \operatorname{IgM}$ and $\mathrm{C} 3$ & $\begin{array}{l}\text { As LM. Subendothelial, } \\
\text { intramembranous and } \\
\text { subepithelial EDD. Numer- } \\
\text { ous intramembranous ex- } \\
\text { tensions of mesangial cell } \\
\text { cytoplasm }\end{array}$ \\
\hline \multirow[t]{2}{*}{10} & $1 \mathrm{st}$ & July 1971 & MPGN & $\begin{array}{l}\text { Segmental + + IgM and } \\
\text { C3 }\end{array}$ & $\begin{array}{l}\text { As LM. Occasional } \\
\text { mesangial and para- } \\
\text { mesangial EDD }\end{array}$ \\
\hline & 2nd & March 1974 & MPGN $\rightarrow$ sclerosis & $\begin{array}{l}\text { Focal and segmental } \\
++C 3 \text { and }+ \text { IgM }\end{array}$ & $\begin{array}{l}\text { As first biopsy, but with } \\
\text { increase in mesangial } \\
\text { matrix }\end{array}$ \\
\hline 11 & $1 \mathrm{st}$ & Feb. 1973 & Variable MPGN & $+\operatorname{IgM}$ and $\mathrm{C} 3$ & $\begin{array}{l}\text { As LM. No definite EDD } \\
\text { seen }\end{array}$ \\
\hline
\end{tabular}

MPGN = diffuse mesangial proliferative glomerulonephritis.

NLMC $=$ no significant light microscope changes.

$\mathbf{L M}=$ Light microscopy.

$\mathrm{EDD}=$ electron dense deposits. 
The ANF is fallible as a screening test for SLE. While false positives are frequent, more significantly, the test may initially be negative. Linstedt et al. (1977) have reported 7 patients with lupus nephritis in whom a persistently negative ANF was associated with positive anti-DNA antibodies. In common with others, the present authors have found anti-DNA antibody and serum complement levels valuable in making a diagnosis (Davis et al., 1973; Cameron et al., 1976). While isolated abnormal levels occurred in the non-lupus patients, the association of a positive ANF, high anti-DNA antibody, and low complement levels have usually occurred in those in whom lupus has been diagnosed. The late appearance of a positive ANF in the absence of other clinical or laboratory evidence of disease activity should suggest a cause other than SLE.

Cohen and Canosa (1972) have commented that lupus patients frequently fail to fulfill the American Rheumatism Association criteria for the diagnosis at first presentation and this has been the experience of the present authors. A single negative ANF must not be accepted as excluding SLE. Repeated estimations are required and, when accompanied by other immunological measurements, may make earlier diagnosis possible. As therapy for severe renal lupus improves, this becomes increasingly desirable.

\section{References}

Alarcon-Segovia, D. (1976) Drug-induced antinuclear antibodies and lupus syndromes. Drugs, 12, 69.

Alarcon-Segovia, D., Wakim, K.D., Worthington, J.W. \& WARD, L.E. (1967) Clinical and experimental studies on the hydralazine syndrome and its relationship to systemic lupus erythematosus. Medicine, Baltimore, 46, 1.

Baldwin, D.S., Gluck, M.C., Lowenstein, J. \& Gallo, G.R. (1977) Lupus nephritis. Clinical course as related to morphological forms and their transitions. American Journal of Medicine, 62, 12.

BARTHolomew, B.A. (1974) Antinuclear antibody tests as a clinically selected screening procedure. American Journal of Clinical Pathology, 61, 495.

BuRnhaM, T.K. (1972) Antinuclear antibodies in patients with malignancies. Lancet, 2, 436.

Cameron, J.S., Lessoff, M.H., OgG, C.S., Williams, B.D. \& Williams, D.G. (1976) Disease activity in the nephritis of systemic lupus erythematosus in relation to serum complement concentrations. Clinical and Experimental Immunology, 25, 418.

Cameron, J.S., Turner, D.R., Vosnides, G., Liebowitz, S., Lessof, M.H., Ogg, C.S., Chantler, C. \& Brown, C.B. (1977) The kidney in systemic lupus erythematosus. In: Seminars in Nephrology (Ed. by Becker, E.L.), p. 41, John Wiley and Sons, New York.

Cathcart, E.S., Idelson, B.A., Scheinberg, M.A. \& COUSER, W.G. (1976) Beneficial effects of methyl prednisolone "pulse" therapy in diffuse proliferative lupus nephritis. Lancet, 1, 163.

Cavallo, T., Cameron, W.R. \& Lapenas, D. (1977) Immunopathology of early and clinically silent lupus nephropathy. American Journal of Pathology, 87, 1.

Conen, A.S. \& CANosA, J.J. (1972) Criteria for the classifi- cation of systemic lupus erythematosus - Status 1972. Arthritis and Rheumatism, 15, 540.

Comerford, F.R. \& CoHen, A.S. (1967) The nephropathy of systemic lupus erythematosus. An assessment by clinical, light and electron microscopic criteria. Medicine, 46, 425.

CrYer, P.E. \& Kissane, J. (1976) Serum and urine paraprotein and filling defects in the spleen. American Journal of Medicine, 60, 531.

Davis, P., Atkins, B., Jasses, R.G. \& Hughes, G.R.V. (1973) Criteria for classification of SLE. British Medical Journal, 2, 88.

Dosa, S., Cairns, S.A., Lawler, W., Mallick, N.P. \& SLOTKI, I.N. (1978) The treatment of lupus nephritis by methyl prednisolone pulse therapy. Postgraduate Medical Journal, 54, 628.

Dujovne, I., Pollak, V.E., Pirani, C.L. \& Dillard, M.G. (1972) The distribution and character of glomerular deposits in systemic lupus erythematosus. Kidney International, 2, 33.

Elsas, L.J., Hayslett, J.P., Spargo, B.H., Durant, J.L. \& ROSENBERG, L.E. (1971) Wilson's disease with reversible tubular dysfunction. Correlation with proximal tubular structure. Annals of Internal Medicine, 75, 427.

EPSTEIN, W.V. (1977) Laboratory tests in rheumatic diseases. Medical Clinics of North America, 61, 377.

FeltKamp, T.E.W., Dourhout-Mees, E.J. \& Nieuwenhuis, M.G. (1970) Auto-antibodies related to treatment with chlorthalidone and methyl dopa. Acta medica scandinavica, $187,219$.

Friou, G.J. (1972) In: Arthritis and Allied Conditions (Ed. by Hollander, J. L. \& McCarthy, D. J.), p. 172. Lea \& Febiger, Philadelphia.

HugheS, G.R.V. (1974) Systemic lupus erythematosus. British Journal of Hospital Medicine, 12, 309.

Husain, M., Neff, J., Daily, E., Townsend, J. \& Lucas, F. (1974) Antinuclear antibodies, clinical significance of titres and fluorescence patterns. American Journal of Clinical Pathology, 61, 59.

Koffler, D., Agnello, V., CARr, R.I. \& Kunkel, H.G. (1969) Variable patterns of immunoglobulin and complement deposition in the kidneys of patients with systemic lupus erythematosus. American Journal of Pathology, 56, 305.

LeVinsky, R.J., Cameron, J.S. \& Soothill, J.F. (1977) Serum immune complexes and disease activity in lupus nephritis, Lancet, i, 564.

LindstedT, G., LUNDberg, P-A., Westberg, G. \& KAYSER, B. (1977) SLE nephritis with positive tests for antibodies against native DNA but negative tests for anti-nuclear antibodies. Lancet, ii, 135.

Meadows, R. (1978) In: Renal Histopathology. A Light, Electron and Immunofluorescent Microscopy Study of Renal Disease, 2nd edn, p. 393. Oxford University Press.

Pollak, V.E. \& PIRANI, C.L. (1974) Pathology of the kidney in systemic lupus erythematosus: serial renal biopsy studies and the effects of therapy on kidney lesions. In: Lupus Erythematosus (Ed. by Dubois, E. L.) 2nd edn., p. 72. University of Southern California Press, Los Angeles.

Pollak, V.E., Pirani, C.L. \& Schwartz, F.D. (1964) The natural history of the renal manifestations of systemic lupus erythematosus. Journal of Laboratory and Clinical Medicine, 63, 537.

RoTHFIELD, N.F. (1977) Kidney in lupus erythematosus. In: Kidney in Systemic Diseases (Ed. by Massry, S. G.), p. 128. S. Karger, Basel.

Simenoff, M.L. \& Merrill, J.P. (1964) The spectrum of lupus nephritis. Nephron, 1, 348.

Svec, K.H. \& VEIT, B.D. (1967) Age-related antinuclear factors: immunological characteristics and associated clinical aspects. Arthritis and Rheumatism, 10, 509. 